\section{COMPARATIVE STUDY ON PRECAST BUILDING CONSTRUCTION AND CONVENTIONAL BUILDING CONSTRUCTION FOR HOUSING PROJECT IN SARAWAK}

\author{
Tan Let Hui, Ng Chee Khoon*
}

Faculty of Engineering, Universiti Malaysia Sarawak (UNIMAS), 94300, Kota Samarahan, Sarawak, Malaysia
Article history

Received

16 June 2019

Received in revised form

4 October 2019

Accepted

1 November 2019

Published online

25 December 2019

*Corresponding author ckng@.unimas.my

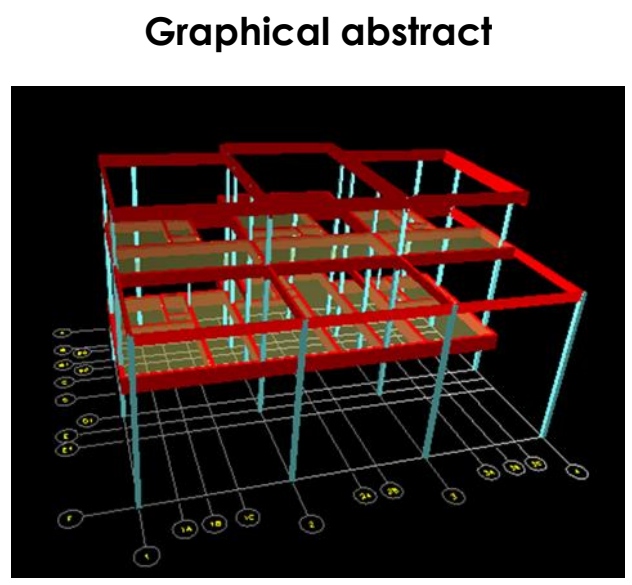

\begin{abstract}
This paper presents an overview on the comparative study between the precast and conventional building construction methods for housing project in Sarawak. In this study, a residential building project with double-storey terrace houses was chosen for the comparative study as they have typical structural layout plans with minor variation. The same building was designed into both conventional and precast structural layout respectively in order to obtain direct comparison results. To ensure the results obtained are representative and unbiased, the structural components integrated in both construction methods are listed and each critical cost component, for instance the project direct and indirect costs were broken down further in order to evaluate the total building construction costs. From the research results, it can induce the relationship between the time and costs evaluation. The overall construction period for the conventional building construction method was 240 days while the precast building construction method was 82 days. As compared across the results for the project construction costs, it shows that precast construction method with RM 354,969.50 is more cost effective with about $19 \%$ less than the conventional building method with total amount of RM 422,687.85. The results reflect the significance on selection of the construction method, namely the precast building construction method not only can shorter the construction periods but also reduce the construction costs since it reduces greatly the expenses on the project direct costs particularly the machineries costs.
\end{abstract}

Keywords: Precast construction method, conventional construction method, comparative study, critical cost component, project total costs

\begin{abstract}
Abstrak
Kajian ini membentangkan perbandingan antara kaedah pembinaan pratuang dan konvensional. Dalam kajian ini, projek bangunan kediaman dengan rumah teres bertingkat dua telah dipilih untuk menjalani kajian perbandingan. Projek tersebut mempunyai pelan lukisan struktur yang tersusun dan teratur dengan perbezaan yang kecil. Bangunan yang sama telah direka dalam pelan lukisan struktur konvensional dan pratuang untuk mendapatkan hasil perbandingan secara langsung. Untuk memastikan hasil kajian yang tepat, komponen struktur yang diintegrasi dalam kedua-dua kaedah pembinaan telah disenaraikan untuk menentukan setiap komponen kos kritikal, contohnya kos langsung dan tidak langsung. Dengan itu, kos pembinaan keseluruhan bangunan boleh dinilai. Penyelidikan ini telah menganalisiskan hubungan antara masa dengan kos. Tempoh pembinaan keseluruhan bagi kaedah pembinaan konvensional ialah 240 hari manakala kaedah pembinaan
\end{abstract}


pratuang adalah 82 hari. Hasil kajian kos pembinaan projek menunjukkan bahawa kaedah pembinaan pratuang ialah RM 354,969.50. Kaedah pembinaan pratuang lebih kos efektif dengan sebanyak $19 \%$ kurang daripada kaedah pembinaan konvensional yang berjumlah RM 422,687.85. Hasilnya menunjukkan kepentingan pemilihan kaedah pembinaan. Kaedah pembinaan pratuang bukan sahaja dapat memendekkan tempoh pembinaan tetapi juga mengurangkan kos pembinaan dengan mengurangkan perbelanjaan pada kos langsung projek khususnya dalam pembiayaan mesin.

Kata kunci: Kaedah pembinaan pratuang, kaedah pembinaan konvensional, kajian perbandingan, komponen kos kritikal, jumlah kos projek

(c) 2020 Penerbit UTM Press. All rights reserved

\subsection{INTRODUCTION}

The conventional construction method is the oldest method which has been practiced in the construction industry worldwide. The concept of conventional construction method is commonly referred to as structural components that are fabricated on construction site, on-site installation of steel reinforcements, and the use of timber or plywood formworks for the casting of components. Andres and Smith [1] defined conventional construction method as more expensive since it consumes more raw materials such as timber formworks and steel reinforcements during the on-site fabrication of building components. It also uses more labours for the cast in-situ works. Due to high labours consumption for site works and low speed construction, conventional construction method is more costly from Badir and Kadir [2]. Despite the fact, conventional buildings are mostly built from conventional construction method.

On the other hand, precast construction method is specific to structural components which are standardised and prefabricated or produced off-site (factories or plants that are located away from the construction site). Construction Industry Development Board [3] explained the precast construction method has emerged as a new fast track construction method to boost the growing economy. It raises the significant advantages in terms of shortened construction time, lower overall project cost as well as better quality. As stated by Rohana and Siti [4], the components are then transported and assembled onsite. Malaysia construction industry defines precast construction method as industrialised building system (IBS) as it involves mass production of components through industrial methods as stated by Azhari et al. [5]. Precast construction method has been defined by various researchers as an alternative construction method towards the adoption of prefabricated and mass production of the building works which tends to improve the productivity, quality, time and cost saving. Dineshkumar and Kathivel [6] explained that the rapid construction rate by adopting precast construction method because the method reduces unnecessary handling and equipment time.
To date, conventional construction method still cannot get rid of the problems of long construction time, low productivity, poor safety records, and large quantities of waste (Egan [7]; Eastman [8]; Azam et al. [9]). Instead, Malaysia construction industry worked a great attempt in the adoption of precast construction method. Ismail and Shaari [10] interpreted precast construction method as not aimed to substitute the conventional construction method but an approach to decrease the reliance on labour, improved productivity with shorter construction time and maintain the quality. Lai [11] indicated precast construction method as an attempt to show greater productivity, shorter construction period, improved quality and reduction in overall construction cost in large-scale precast buildings in Malaysia. Yang and Yunus [12] and Shamsuddin et al. [13] viewed that precast construction method is able to increase the profit in long-term for the stakeholders as the cost of the labour and materials can be reduced. In contrast, Azam and Zanarita [14] stated that precast construction method does not have much difference in term of material saving as compared to conventional construction method but it has benefits in terms of quality and labour saving. Virendravyas [15] conducted a comparative study between precast and conventional construction method and stated that precast construction method registered almost the whole saving on plastering and finishing works. Similarly, according to the previous data reported from Construction Industry Development Board (CIDB) [16], it shows that the precast construction method gives rise to cut down the construction costs as much as $15 \%$ in some instances.

According to Norazmi [17] Cost is regarded as the main critical factor in determining the nature of business, not least in the construction industry. Construction cost is the factual data which consists of cost estimating till finished quantities of a building. It is the fundamental to predict and plan the total executing cost of a construction work. Therefore, it is the most rational criteria and vital for evaluating the choice on construction method. Previous research findings obtained from Hafiz [18] on the comparison of material costs between precast half slab and conventional suspended slab tackled from unit cost 
per floor gross area can be presented into more delicate way.

In the comparative study between precast construction method and conventional construction method, there are five types of key comparative methods for the estimation on construction project total cost. These include the cubic content estimation; floor area; unit valuation; bill of quantities; and approximate quantities. Regarding on this, Jabatan Kerja Raya [19] stated that approximate quantities is the most accurate method for estimating the project total costs. In between, the costdeterminants have to include all the direct and indirect costs.

During the construction process on site, time consumption must be well controlled to avoid the cost overhead and it is also important to consider the general expenses especially in precast construction method during its onsite installation process. It is realised that the current construction industry still cannot fully surmount the significant effects on time delay. According to Akintoye et al. [20] in the study on cost and time overruns of projects in Malaysia, it was discovered that among 359 construction projects in Malaysia, only $18.2 \%$ of the public sector projects and $29.5 \%$ of private sector projects were completed on time with an average percentage of $49.7 \%$ projects suffering time overrun and delay. The time overrun and delay resulted in the delay costs money. Since time element influentially determines the overall construction cost in the local construction industry, therefore, it is important to select the alternate construction method so as to minimise the root cause of the time delay such as the issue of inclement weather for site works. Phang [21] observed that precast construction method is better in cost saving as it consumes less construction time since the construction operation is less affected by bad weather.

Construction method also affects the choice of 'materials and methods' used in construction. Total building cost will be affected significantly by the choice of construction methods. Chan [22] conducted a study on the comparison of construction cost and choice of methods through a quantitative framework study on the construction material, labour and capital cost indices for evaluating the framework structure of the construction industry. It was found that the life-cycle cost of buildings can be reduced if the construction method is easily adopted; the involvement from large numbers of cheap labour forces; availability of abundant construction materials without the added transportation cost; inexpensive maintenance cost and lower investments on the methods used. On the matter of transportation cost, Warszawski [23] mentioned that transportation is the main barrier that has limited the design considerations on the size and weight of the completed precast structural components in Malaysia. The length of a volumetric structural component should not exceed $12 \mathrm{~m}$. The precast component should not exceed the maximum height and weight of $4.5 \mathrm{~m}$ and 7 tonnes, respectively, when loaded on the trailer. The components could not enter the highway system if they exceed a height limit ranging from 4.8 to $5.1 \mathrm{~m}$. Mobile cranes commonly with 20-ton, 50-ton, or 70ton capacity maybe required for the hoisting to install the precast structural components. This may somehow increase the operational cost of the construction project. In addition, the construction development area to the fabrication plant should be within the distance of 50 to $100 \mathrm{~km}$ for economical transportation cost.

As for the wage rate, it is the direct cost per hour paid to the workmen whereas the indirect labour costs are the payments made by a contractor on the behalf of employee. Therefore, the labour rate is the total of direct and indirect cost per hour from Davis [24]. According to Haron et al. [25], conventional construction method will cost more in the whole construction project cost due to the cost for labour, raw material and longer time duration of the construction project. According to Zarim [26], the factors that determined the benefits of the precast construction method includes the labour, of which the number of labours can be reduced, easier coordination, less raids by authorities, less social problems and create more profit.

Lim et al. [27] also noticed that conventional construction method is very labour intensive and unproductive. Wet works such as the fabrication of steels on site have higher wastage, creates housekeeping problems and lead to potential spalling due to poor workmanship. Quality pertaining to bulging formwork and honeycombing problems, result in abortive works like hacking and patching. Advantages of precast construction method includes self-supporting ready-made components are being used, so the need for formwork, and scaffolding is greatly reduced. Time spent in bad weather environments at the construction site is minimised. Less waste may be generated and hence more sustainable. On the other hand, challenges of precast construction method includes careful handling of precast components such as concrete panels. Attention has to be paid on the strength and corrosion-resistance and leaks of the joining of precast sections to avoid failure of the joint. Transportation cost may be higher for precast components. Large precast components require heavy-duty cranes and precision measurement and handling to place in position. As the previous research findings from Akash and Venkateswarlu [28] stated that precast building construction method only raises the costs effectiveness in large scale project with building projects more than 5 storey because the results addressed the imitation by noticing that the increase or decrease in costs as a result of one more or one less unit of output causing the cost increase is more marginal than substantial. But, mass production of repetitive precast units will eventually lower down the cost to a level comparable to conventional construction. 
Therefore, this research paper intends to carry out on the comparative study of conventional and precast construction methods with the focus on low rise double storey housing projects. The types of structural components used for the comparative studies are addressed and critical elements involved in the comparative studies are also identified herein. Finally, the overall construction costs are evaluated for both the building construction methods in order to identify the more cost effective building construction method.

\subsection{METHODOLOGY}

This section will give details on the research project that has been conducted. This research involved the comparative study between the precast and conventional building construction methods. The comparative study is focusing on residential project.

\subsection{Scope of Study}

The residential project was chosen as the study scope. Residential projects have typical structural layout plans and are repetitive with regardless minor variation might occur. This makes the direct comparison results between both building systems become more representative and unbiased.

Comparison analysis was performed by designed the same residential project plan layout as shown in Figure 1 and Figure 2 into conventional and precast building structural layout plans. The structural components used both in the design of precast building construction and conventional building construction were then identified and listed in detailed. The construction project costs with respect to direct and indirect costs for each building construction methods were breakdown in further to evaluate the final overall building total cost. Figure 2 showed the elevation plan of the building in $\mathrm{x}$-cut section (X-Section).

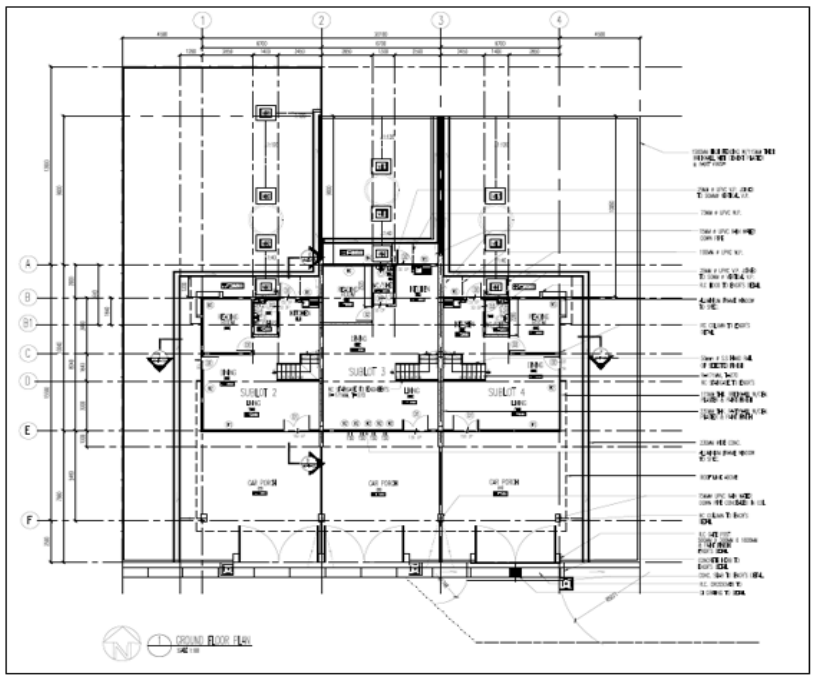

Figure 1 Ground floor plan for the 2-storey terrace house

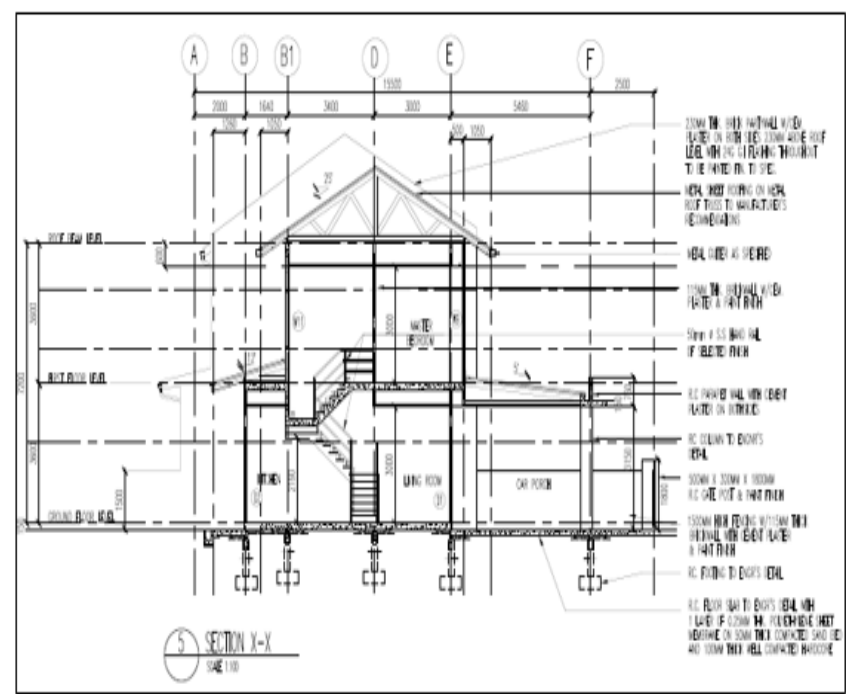

Figure 2 Elevation plan of the 2-storey terrace house in $\mathrm{x}$ section

\subsection{Double-Storey Terrace House with Conventional Building Construction}

The submission building drawing was converted into conventional building construction structural design layout plan by using the Esteem plus 6.6.3.3. The material cost estimation for the conventional building construction method was obtained through the material quantity take-off based on the designed drawing of the building structure plans. Before gathering labor hours, the works breakdown analysis needs to be carried out. Time scheduling was done by using Work Breakdown Structure (WBS) constructed by using Microsoft Project. The sequence and time needed for every task was listed in detailed. This analysed the total time needed for the project works. Based on the schedule, time planning done for the project would be determined. Time estimation could be done more accurately in accordance to local condition.

\subsection{Double-Storey Terrace House with Precast Building Construction Method}

The same submission building drawing was converted into precast building construction design. The structure components are design based on the IBS Catalogue for Precast Concrete Building System Revision 2017 from Construction Research Institute of Malaysia (CREAM) [29]. All the designs are referred to the competent engineer from precast manufacturer and consultant firm. The material cost estimation for the precast building construction method was identified through the number of units of precast components customized and installed in the project. Work Breakdown Structure (WBS) is used to specify the project activities in order to identify the total labor hours used for the precast project. The labor 
hours included the time consumption on customize components and installation of precast components.

\subsection{Critical Elements for Comparative Studies}

In this research study, both the conventional building construction method and precast building construction method had considered the same critical components to undergo the comparative evaluation and analysis. This was to avoid discrepancy in methodology and to ensure the results are more comparable between both construction methods. Since the project total cost is the ultimate aim of this study, therefore, the cost estimation and time management are the two main critical elements integrated in this study.

In this study, direct and indirect costs are the principal components for project total cost. The end of the accountable results are calculated based on the building cost estimating formula as:

\section{Total Project Cost $=$ Project Direct Costs + Project Indirect Costs}

The project direct costs considered in this study included the material costs, labor costs, subcontractor cost and equipment costs. The project indirect costs included the facilities, personnel costs, and administration costs.

Furthermore, time schedule described the time managements and workflows of the construction projects in between assisted in the cost-estimation. Each elements of the project direct and indirect costs were stated in detailed in the followings.

\subsection{Assumption}

Several assumptions had made on the elements for cost estimating and time scheduling. In order to obtain more viable results, the assumptions were made to be the same for both building construction methods. The followings are some of the assumptions made in this research.

\subsubsection{Time Assumption}

In this research study, a Gantt-chart with workbreakdown structure was used to represent the timeline of the building project. The productive period such as the total number of working days is assumed as 6 days per week and the total working hours was assumed to be 8 hours per day. This was accordance to the Malaysian Employment Act 1955 (Laws of Malaysia, 2018) [30]. The entire nonproductive days within the building construction period which included the Sundays and Public Holidays.

\subsubsection{Cost Assumption}

The cost assumptions for materials, labour, plant and equipment costs used in this research projects were all referred to the Malaysian building material prices as published by Construction Industry Development Board (CIDB) [31], which was last updated in 2017.

\subsection{Comparison Analysis}

To obtain accurate and comparable analysis, all the structural components used both in the projects of precast building construction and conventional building construction were listed out in detail. The construction project total cost on both the projects of precast building construction and conventional building construction were further broken down into each category such as direct and indirect cost. Lastly, the construction project total cost between precast building construction and conventional building construction were compared in term of its time analysis and cost analysis. After the analysis of the projects, both the results of precast and conventional building construction methods in terms of time, cost and quality analysis will be compared. For time analysis, the construction period was prepared. This helps in determining the construction method that has more time saving. The direct and indirect costs were also compared. This research compares each perspective in detail so that to determine the advantages and disadvantages of each construction method respectively.

\subsection{RESULTS AND DISCUSSION}

\subsection{Time and Schedule Analysis}

The project schedule for both conventional and precast building construction methods are constructed. Table 1 summarizes the time and schedule analysis for both the construction methods. It aims to analyse the time consumption on respective tasks that have been carried out throughout the building construction periods.

Table 1 Building Construction Periods for Conventional and Precast Building Construction Method

\begin{tabular}{|l|c|c|}
\hline \multirow{2}{*}{ Phase / Task Name } & \multicolumn{2}{|c|}{ Durations } \\
\cline { 2 - 3 } & $\begin{array}{c}\text { Conventional } \\
\text { Building } \\
\text { Construction } \\
\text { Method }\end{array}$ & $\begin{array}{c}\text { Precast Building } \\
\text { Construction } \\
\text { Method }\end{array}$ \\
\hline Site work & 8 days & 8 days \\
\hline Foundation & 54 days & 54 days \\
\hline $\begin{array}{l}\text { Construction of } \\
\text { ground floor }\end{array}$ & 98 days & 77 days \\
\hline $\begin{array}{l}\text { Construction of first } \\
\text { floor }\end{array}$ & 63 days & 74 days \\
\hline $\begin{array}{l}\text { Construction of } \\
\text { mezzanine floor }\end{array}$ & 24 days & 70 days \\
\hline $\begin{array}{l}\text { Construction of } \\
\text { roof }\end{array}$ & 240 days & $\mathbf{8 2 ~ d a y s ~}$ \\
\hline $\begin{array}{l}\text { Overall } \\
\text { Construction } \\
\text { Periods }\end{array}$ & & \\
\hline
\end{tabular}


The excavation for the site was the first major activity that sits on the critical path of the overall project. Based on Table 1, it shows that both the conventional and precast building construction methods have taken up 8 days for site work and 54 days for the foundation works. For the construction of the superstructure of the building project, the conventional building construction method showed the durations used to construct the ground floor was 98 days (from 17/3/2017 - 15/7/2017), 63 days (from $19 / 7 / 2017$ - 7/10/2017) were used to finish constructed the first floor. In addition, 24 days (from $23 / 8 / 2017$ - 26/9/2017) were used to construct the mezzanine floor and 26 days (from 27/9/2017 $26 / 10 / 2017)$ for the construction of roof. These accumulated a total durations of 240 days. In contrast, the precast building construction methods consumed of 77 days (from 1/2/2017 - 5/4/2017) for the construction of ground floor, 74 days (from $9 / 1 / 2017$ - 8/4/2017) for the construction of first floor and 70 days (from 16/1/2017 - 7/4/2017) for the construction of mezzanine floor. The durations for constructed the roof were 66 days (from 23/1/2017 $10 / 4 / 2017)$. It consumed a total durations of 82 days for these phases. Thus, it showed that precast building construction method has shorten the construction period by 158 days or about $66 \%$ more time effective in constructing the building main structures as compared to conventional building construction method. Although the conventional building construction method shows shorter construction period for the first floor, mezzanine and roof, but the practiced of work sequences in conventional building method of finish-to-start has caused the cumulative in the durations of construction thus it raises the longer durations as compared to precast building construction method since the precast practiced the start-to-start work sequences and resulted in less cumulative in term of time.

\subsection{Building Material Costs}

From the structural analysis and the results obtained, it can be concluded that the main structural components involved in this research study includes the slabs, beams, columns, bricks, wall panels, and staircase. The foundation structures used in this research study was the shallow foundation and its structural components were used for both the conventional and precast construction methods. Table 2 compares the building material costs for conventional building construction method and precast building construction method.

Based on Table 2, it was found that the same total material costs of RM 23,547.25 is used to construct the foundation for both conventional and precast building construction methods. In between, the subtotal of the slab material costs needed for the conventional method is RM 16,869.25 while for precast methods only consumed a total of RM $4,718.00$.
Table 2 Comparison of building material costs for conventional building construction method and precast building construction method

\begin{tabular}{|l|l|l|}
\hline $\begin{array}{r}\text { Construction } \\
\text { Types of } \\
\text { Component }\end{array}$ & $\begin{array}{c}\text { Conventional } \\
\text { Building } \\
\text { Construction } \\
\text { Method }\end{array}$ & $\begin{array}{c}\text { Precast } \\
\text { Building } \\
\text { Construction } \\
\text { Method }\end{array}$ \\
\hline Foundation & RM 23,547.25 & RM 23,267.35 \\
\hline Beam & RM 39,475.00 & RM 125,297.00 \\
\hline Column & RM 6,742.65 & RM 45,610.80 \\
\hline Slab & RM 16,869.25 & RM 4,716.00 \\
\hline Wall Panel & RM 15,015.20 & RM 4,835.80 \\
\hline Staircase & RM 4,225.50 & RM 3,500.00 \\
\hline Subtotal:- & RM 105,874.85 & RM 207,228.95 \\
\hline
\end{tabular}

Precast slab is cheaper as compared to conventional slab as it reduces the cost on formworks since it is casted by using repeated able steel moulds. In addition, precast hollow core slabs are integrated in the design caused an additional of saving in terms of material costs for the steel bar as compared to conventional method. In addition, the summation of subtotal of beam material costs for conventional method is RM 39,475.00 but the precast method accounted a higher costs with RM 12, 5297.00. This was mainly due to this project involved varies types of precast design of beams such as TBeam, edge beams or external beams which has led to low repetition and caused higher unit rate of the material costs at the same time. Likewise to the precast columns, it showed higher in material costs with a total of RM 45,610.80, which is almost 6.7 times higher to the subtotal of conventional columns with only RM 6,742.65. Again, this was due to the higher density of the precast columns with higher requirements of rebar content which has raised the higher rebar costs. However, the precast wall panel raised the cost benefits with RM 4,835.80 which caused cost saving of RM 10,179.40 (about 3 times) as compared to the cost of conventional brick walls with RM 15,015.20. The higher wastage for conventional brick walls of $12 \%$ is the main factor that caused the higher material costs as compared to mechanized precast wall panel with minimized wastage. Besides, the cost benefits of the precast building construction method can also be shown through the precast staircase of which the precast staircase with RM 3,500, is $17 \%$ cheaper than the conventional staircase with RM 4,225.50. Same as the discussion for precast slabs, the precast staircase gave cost benefits of which it can reduce the costs spent on the formworks and propping. Thus, as compared to conventional building construction method, the precast building construction method showed cost benefits mainly for precast slabs, wall panels and staircase but shower higher in material costs for precast columns and beams. In terms of the percentage of material consumption costs towards 
the project construction costs, the conventional building construction method only used up $25 \%$ of the project total costs with RM 105,874.85 for material costs but precast building construction method has used $58 \%$ of the project total costs with RM 207,228.95 on the material costs to construct the building superstructure.

\subsection{Breakdown of Cost Components}

In this research project, the principal cost components which includes the material costs, labor costs and plant rates have been considered to calculate the project overall construction costs for both the conventional and precast building construction method. Figure 3 shows the breakdown of project total costs in conventional building construction method whereas Figure 4 shows the breakdown of project total costs in precast building construction method.

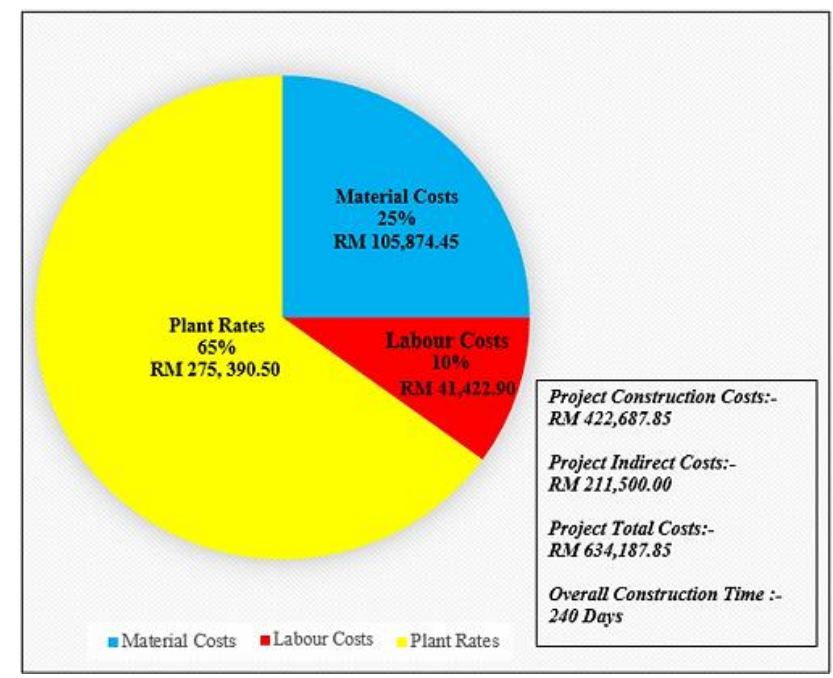

Figure 3 Breakdown of project total costs in conventional building construction method

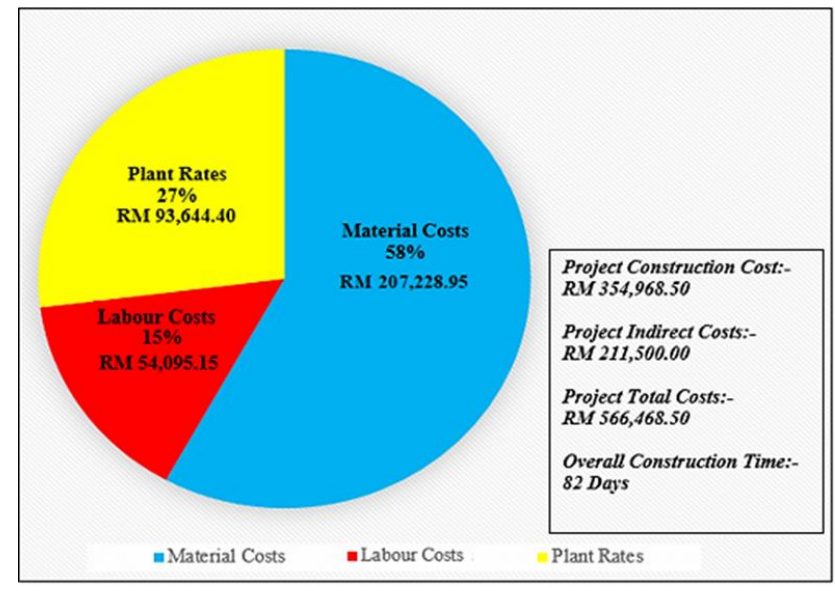

Figure 4 Breakdown of project total costs in precast building construction method
Based on Figure 3, the conventional building construction method distributed the overall project construction costs into $25 \%$ of material costs (RM $105,874.85$ ), $10 \%$ of labor rates (RM 41,422.90) and $65 \%$ of plant rates (RM 275,390.50). Therefore, the plant rates were the highest expenses whereas the labor costs show lowest expenditure with $39 \%$ out of the material costs. On the order hand, as referred to Figure 4, the project construction costs of precast building construction method composed of the expenditure of $58 \%$ on material costs (RM 207,228.95), $15 \%$ on labor costs (RM 54,095.15) and $27 \%$ on plant rates (RM 93,644.40). Thus, it shows that the highest expenditure of precast building construction method is on the material costs while the labor costs were took up approximate $26 \%$ of the material costs and the plant rates takes up approximately $45 \%$ of the material costs.

As compared across the cost components of both conventional and precast building construction methods respectively, it is noticed that the plant rates constituted the highest expenditure in conventional building construction method but not in the precast building construction method. This is mainly related to the overall construction periods of both construction methods. Since the conventional building construction method used up longer construction period of 240 days as compared to shorter construction periods in precast building construction method with only 82 days, it causes the highest in expenditure for plant rates which included the machineries, equipment and tools since the rental fees for those machines and equipment directly related to the time duration. The longer the construction period, the longer the rental periods and thus causes higher charges. In contrast, the shorter construction periods in precast building construction method raised the benefit towards only shorter rental periods required for the machineries such as the crane to carry out the on-site activities, therefore, the rental rates is cheaper.

For the precast building construction method, the material costs constituted the highest of $58 \%$ expenses within the overall project construction costs but conventional building construction method only used up $25 \%$ of the project total costs on the material costs. This indicated that the price charges towards the precast components still exceed the conventional works.

As compared across the labor costs, it is shown that the conventional building construction method spent up of $10 \%$ (RM $41,422.90$ ) out of the project total costs whereas the labor cost of precast building construction method constituent of $15 \%$ (RM $54,095.15)$. The labor costs spent by the precast building construction method showed significant difference of RM 12,672.25, which was about $31 \%$ higher than the labor costs of conventional building construction method. This is mainly due to the precast building construction method required highly skilled labor for both the on-site installation and offsite production activities. Skilled labors have the 
higher basic wage rate as compared to the conventional building construction method. Although the conventional building construction method involved a larger labor size, but it reduced the total labor costs since the labor rate is less skill with lower compensated of labor rate directed to its productivity rate by counted for the total working hours instead of counted by basic wages. This was to denote the usual high fluctuation and mobility of labors in local construction industry.

To sum up, the project construction costs for conventional building construction method is RM $422,687.85$ whereas the project construction costs for precast building construction method is RM $354,968.50$. As summed up a total of RM 211,500.00 for the project indirect costs particularly for the site management personnel such as the site engineers, project manager for the whole development processes into both of the construction methods, it showed that the project total costs for the conventional building construction method is RM $634,187.95$ and the project total costs for precast building construction method is RM 566, 468.50. Thus, the precast building construction method is more cost effective with about $19 \%$ less than the construction cost used by the conventional building construction method. The significance of the results show that the chosen construction method will affect the project total costs.

\subsection{CONCLUSION}

This research presents an overview on the comparative study between the precast and conventional building construction method. In this research, a residential building project with doublestorey terrace houses was chosen for the comparative study since it can provide more viable results as it has typical structural layout plans and are repetitive regardless of minor variation. The same building was designed into both conventional structural layout and precast structural layout respectively in order in order to obtain direct comparison results between the two building construction methods. To ensure the results obtained are representative and unbiased, the structural components integrated in both construction methods are listed and each critical component cost, for instance the project direct and indirect costs were broken down further in order to evaluate the total building construction costs.

The overall construction period for the conventional building construction method was 240 days while the precast building construction method was 82 days. It showed that the precast building construction method is more time effective with less than 158 days or $65 \%$ as compared to conventional building construction method. For the constructions of the main structural components which included the ground floor, first floor, mezzanine and roof, the conventional building construction method has accounted a total durations of 179 days. In contrast, the precast building construction methods consumed only 82 days. Thus, it showed that precast building construction method can shorter the construction period by 97 days or $54 \%$ more time effective when constructs the main building structures or superstructures as compared to conventional building construction method.

In addition, the time analysis is important to evaluate on the project direct costs such as the labor costs and plant rates in the research project. Based on the time analysis, the allocations of tasks, labor size and rental period for machineries and equipment can be deduced. As the results obtained, the conventional building construction method used up 10\% with RM 41,422.90 on the labor costs and $65 \%$ with RM $275,390.50$ on plant rates. Conversely, precast building construction methods consumed only $27 \%$ with RM $93,644.40$ on plant rates, $15 \%$ with RM 54,095.15 on labor rates. The results indicated the expenditure of the plant rate for conventional building construction method is significant different as much as 3 times higher than the plant rates of precast building construction method. However, precast building construction method showed higher cost of RM 12, 6725.25 with 31\% higher than the labor costs of conventional building construction method.

For the material costs to construct the superstructure of the building project, precast building construction method only showed cost benefits in terms of ultilising the precast slab (RM4,718.00), precast staircase (RM3,500.00) and precast wall panel (RM4,835.80) as compared to conventional slab (RM16,869.25), conventional staircase (RM4,225.50) and conventional brick wall (RM15,015.20). It is however, the precast building construction method showed higher material costs in precast column (RM45,610.80) and precast beam (RM125,297.00) as compared to conventional column (RM 6,742.65) and conventional beam (RM39,475.00). Nevertheless, the conventional building construction method only used up $24 \%$ of the project total costs with RM 105,874.85 on the material costs. Conversely, the precast building construction method has used up with more than half of it project total costs, which is $56 \%$ with RM $207,228.95$ for the material costs to construct the building superstructure.

In a nutshell, as compared across each cost components for the project construction costs, it shows that material costs, $58 \%$ with RM207,228.95, is the critical cost component for the precast building construction method while the plant rates, $65 \%$ with RM275,390.50, is the critical cost component for the conventional building construction method. Based on the project overall construction costs, the precast construction method with RM354,968.50 is more cost effective with about $19 \%$ less than the conventional building method which is accounted in total amount of RM422,687.85. The results imply the significance on selection of the construction method, namely the precast building construction method not only can 
shorten the construction periods but also tend to reduce the construction costs since it reduced greatly the expenses on the project direct costs particularly the machineries costs. This results obtained is prior for the future study and the development of the precast building construction method in the construction industry in order to meet the requirement of future productive-based industry in the way of which both aspects of time and costs must achieve its optimum benefits.

\section{Acknowledgement}

The authors would like to acknowledge the SPC - IBS and Precast Concrete Manufacture for the consultations on quotations and prices as reference resources for this research. The authors would also like to acknowledge the Perunding Daya Cipta for provided the terrace house building layout plan as academic purposed. Acknowledgement also given to National Higher Education Fund (Malaysia) for the financial funding to this research.

\section{References}

[1] Andres, C. K., and Smith, R. C. 1998. Principal and Practices of Heavy Construction. 5th Edn. New York, United States. Ozkurt, C., and Camci, F. 2009. Automatic Traffic Density Estimation and Vehicle Classification for Traffic Surveillance System Using Neural Networks. Mathematical and Computer Applications. 14(3): 187-196. DOI: http://dx.doi.org/10.11113/jt.v79.9987.

[2] Badir, Y. F. and Kadir, M. R. A. 1998. Theory of Classification and Baddir-Razali Building Systems Clsassification. Bulletin Bulanan IJM. IJM International Justice Mission. IJM International Journal of Multilingualism, Jurutera, pp. 50-56. Yoneyama, A., Yeh, C. H. and JayKuo, C. C. 2005: Robust Vehicle and Traffic Information Extraction for Highway Surveillance. Eurasip Journal on Applied Signal Processing 2005. 2305-21. DOI: http://dx.doi.org/10.11113/jt.v79.9987.

[3] Construction Industry Development Board (CIDB). 2017. Industrialised Building Systems (IBS) Homepage Construction Industry Development Board (CIDB). Retrieved from http://www. cidb.gov.my/cidbv3/.

[4] Rohana, M. and Siti, S. K. 2013. Enhancing the Quality of Life by Adopting IBS: An Economic Perspective on Mechanisation and Automation. Procedia-Social and Behavioral Sciences. 101: 71-80.

[5] Azhari, A., Kamarul, A. M. K, Khairolden, G., Maria, Z. M. Z Sanusi, S., Taksiah A. M., Zuhairi A. H. 2012. Drivers and Barriers to Industrialised Building System (IBS) Roadmaps in Malaysia. Malaysian Construction Research Journal. 9(1).

[6] Dineshkumar, N., \& Kathirvel, P. 2015. Comparative Study on Prefabrication Construction with Cast In-situ Construction of Residential Buildings. International Journal of Innovative Science, Engineering \& Technology. 2(4): 527-532.

[7] Egan, J. 1998. Rethinking Construction, Report of the Construction Task Force on the Scope for Improving the Quality and Efficiency of UK Construction Industry. Department of the Environment, Transport and the Regions, London.

[8] Eastman, C. M. 2008. Relative Productivity in the AEC Industries in the United States for on-site Activities. Journal of Construction Engineering and Management. 134(7): 517-526.
[9] Azam, N., Haron, Rahim, M., Syazwan, M. 2013. Construction Cost Comparison between Conventional and Formwork System for Condominium Project. International Journal of Advanced Studies in Computer Science and Engineering. 2(5): 19-25.

[10] Ismail, E., Shaari, S. N. 2003. Promoting the Usage of Industrialised Building System (IBS) and Modular Coordination (MC) in Malaysia. Construction Industry in Engineers (Board of Engineer Malaysia).

[11] Lai, K. W. 2005. Construction Labour Productivity Study for Conventional Cast In-situ and Precast Construction Methods. Master of Science Thesis. Malaysia University of Science and Technology, Malaysia.

[12] Yang, J. and Yunus, R. 2011. Sustainability Criteria for Industrialised Building Systems (IBS) in Malaysia. Procedia Eng. 14: 1590-1598.

[13] Shamsuddin, S. M., Zakaria, R. and Mohamed, S. F. Z. 2013. Economic Attributes in Industrialised Building System in Malaysia. Procedia-Socialand Behavioral Science. 105: 75-84.

[14] Azam, N. H., and Zanarita, A. M. 2012. Construction Cost Variance for school Project in Malaysia. European International Journal of Science and Technology. 1(1): 4355.

[15] Virendravyas. 2015. Survey of Precast Concrete Method and Cast-in-situ Concrete Method. International Journal of Engineering and Technical Research (IJETR). 3(11): 70-73.

[16] Construction Industry Development Board (CIDB). 2017. Industrialised Building Systems (IBS) Homepage, Construction Industry Development Board (CIDB). Retrieved from http://www. cidb.gov.my/cidbv3/.

[17] Norazmi, A. B. 2008. Exploring the Types of Construction Cost Modelling for IBS projects in Malaysia. Conference Proceeding, lst International Conference on Industrialised, Integrated Intelligent Construction, Loughborough, United Kingdom.

[18] Hafiz, Z., Hafizal, H., Zainal, A., \& Zakwan, R. 2016. Cost Comparison on Industrialised Building System (IBS) and Conventional Method for School Construction Project. Journal of Scientific Research and Development. 3(4): 95101.

[19] Jabatan Kerja Raya. 2017. School Building Cost Data from Element Cost Analysis Form ECA Form. Public Work Department, Malaysia.

[20] Akintoye, Akintola, Roshana, Takim. 2002. Performance Indicators for Successful Construction Project Performance. 18th Annual ARCOM Conference. 2: 545555.

[21] Phang, A. T. 2017. Facilities and Incentives for Industrialised Building Systems in Malaysia. Modern Construction Technologies Industrialised Building Systems (IBS). Functional Designs, Cost Savings, \& Sustainable Practices. Available at: http://rehdainstitute.com/event/ibs-2017/. Retrieved on 5 June 2017.

[22] Chan, T. K. 2011. Comparison of Precast Construction Costs - Case studies in Australia and Malaysia. Procs 27th Annual ARCOM Conference, 5-7 September 2011, Bristol, UK, Association of Researchers in Construction Management. 3-12.

[23] Warszawski, A. E. D. 1999. Industrialized and Automated Building Systems: A Managerial Approach. E\&FN Spon, London.

[24] Davis Langdon Management Consultant. 2010. Literature Review of Life Cyscle Costing (LCC) and Life Cycle Cost Analysis (LCCA)-Document Review.

[25] Haron, Nuzul \& Syazwan Md. Rahim, Mohd. 2013. Construction Cost Comparison between Conventional and Formwork System for Condominium Project. International Journal of Advanced Studies in Computer Science and Engineering. 2(5): 19-25.

[26] Zarim, A. B. 2017. Industrialised Building Systems. Modern Construction Technologies Industrialised Building Systems (IBS), Functional Designs, Cost Savings, \& Sustainable Practices. 
http://rehdainstitute.com/event/ibs-2017/. Retrieved on 5 June 2017.

[27] Lim, M. H., Maksat, O., Serdar, D., Syuhaida, I. 2017. Significant Contributors to Cost Overruns in Construction Projects of Cambodia. Cogent Engineering Journal. 4(1): $1-10$.

[28] Akash, L., \& Venkateswarlu, D. 2016. Design, Cost \& Time Analysis of Precast \& RCC Building. International Research Journal of Engineering and Technology (IRJET). 3(6): 343350.

[29] Construction Research Institute of Malaysia (CREAM). 2017. IBS Catalogue for Precast Concrete Building System
Revision 2017. Kuala Lumpur, Malaysia: Lembaga Pembangunan Industri Pembinaan Malaysia

[30] Laws of Malaysia. 2018. Malaysian Employment Act 1955. Retrieved from https://www.lo.org/dyn/natlex/docs/WEB TEXT/48055/66265/E55mys01.htm.

[31] Construction Industry Development Board Malaysia (CIDB). 2017. Major Materials Pricing Schedule. Retrieved from

https://www.yumpu.com/en/document/view/5824795/ci db-average-price-of-building-materials-sm-bmdam. 